\title{
Преводна и критичка рецепција романа Педро Парамо Хуана Рулфа у Србији
}

\author{
Владимир J. Карановић* \\ Универзитет у Београду, Филолошки факултет, Катедра за иберијске студије \\ Снежана Б. Јовановић \\ Универзитет у Крагујевцу, Филолошко-уметнички факултет, Катедра за хиспанистику
}

\begin{abstract}
Кључне речи:
Апстракт

Хуан Рулфо

Педро Парамо

мексичка књижевност

XX века

хиспаноамерички

нови роман

преводна рецепција

Полазећи од основних постулата теорије превођења, значаја превода у одређеној културној средини и концепције превођења као првог медијума у интеркултурној комуникацији, у раду је анализиран контекст преводне и критичке рецепције романа Педро Парамо мексичког писца Хуана Рулфа (1918-1986) у нашој културној средини. Анализа се заснива на одабраном корпусу постојећих превода или њихових редакција, док су предмет анализе критичке рецепције пропратни текстови, објављени у виду предговора или поговора преупоредна традуктолошка анализа водима, научни и стручни чланци, као и књижевноисторијска поглавља у монографским публикацијама на српском језику. Традуктолошки вид рецепције представљен је кроз упоредно разматрање и општу филолошку оцену постојећих превода романа, пре свега лингвистичких, семантичких, културолошких видова, који су несумњиво омогућили овом делу лакшу интеграцију и заузимање важног места у систему српске преводне књижевности. (примљено: 12. марта 2021; прихваћено: 4. јуна 2021)
\end{abstract}

www.anali.fil.bg.ac.rs

\section{АНАЛИ}

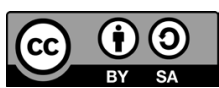

* Филолошки факултет Катедра за иберијске студије

Студентски трг 3

11000 Београд, Србија vladimir.karanovic@fil.bg.ac.rs 


\section{1. Увод}

Сваки облик проучавања механизама и процеса превођења у основи и у почетној фази обухвата лингвистичку анализу, те се подразумева да је ова активност примарно лингвистичког карактера. Међутим, темељнија тумачења $и$ савремене студије традуктологије пажњу посвећују и неким другим областима, проширујући у знатној мери предмет проучавања и на сферу културе у најширем смислу те речи. Превођење је, дакле, интердисциплинарна активност, која методе и аналитичке перспективе може преузимати из других области знања, али чији су циљеви јасно постављени: анализа, развој и примена конкретне методологије и дидактичких модела по којима се текст настао на одређеном језику претвара у текст на неком другом језику (Carbonell i Cortés, 1999: 19-20). Филозофска мисао XX века засигурно нас је усмерила ка спознаји вишеструке функције коју језик има, те говоримо о политичкој, друштвеној, идеолошкој моћи језика. У том смислу превод је део тзв. „контролисаног дискурса“, чији је циљ да се отклоне потенцијалне опасности или уклоне тензије које се могу јавити у оквирима сусрета међусобно непознатих елемената. Превођење тако више није само лингвистичка делатност, већ активност која подразумева сусрет и дијалог између култура, као процес нужне међукултурне комуникације (Манчић, 2010: 48).

Појам „тачност превода“ несумњиво је један од најважнијих чинилаца опште теорије превођења. У преводилачкој пракси неретко се као један од кључних идеала појављује „лепота превода“ (углавном у области књижевног превођења), али нема основа да се такав циљ сматра објективно остваривим с обзиром на то да лепота припада сфери субјективности и личног доживљаја (Bugarski, 1981: 19). Теорија превођења, у најширем смислу, подразумева спој и интеракцију бројних фактора, чинилаца и пропозиција, који морају бити испуњени или присутни како би се уопште могао сагледати процес превођења конкретног дела или дескриптивно вредновати резултат преводилачке активности. Стога Миодраг Сибиновић (1981: 36) правилно оцењује да је теорија превођења не само константно на граници разних дисциплина или класичних научних области, већ је недвосмислено интердисииплинарна област, која подразумева сложен однос међу елементима процеса и међуљудску и међумедијалну комуникацију. Према речима Александре Манчић,

[м]ожда је феномен превођења феномен обележен сталним кретањем између доминације и маргинализације. Са овог становишта, као најочигледнија се намећу разна методолошка питања: Како се уопште неко одлучи да преведе неко дело? Које дело? Ко је његов преводилац? Да ли су преводи резултат планског и институционализованог деловања, или појединачни рад преводилаца и издавача? (2010: 63)

Управо су постављена питања темељ за сваку анализу преводне рецепције одређеног књижевног корпуса у новој култури и преводној књижевности, а пи- 
тање доминације или маргинализације од великог значаја за вредновање импакта превода или пак његове функције у даљој критичкој, преводној, књижевној рецепцији.

Наука о превођењу у себи садржи три дисциплине о којима увек треба збирно говорити када разматрамо питања преводне рецепције, а тек спој све три дисциплине или макар вида проучавања превођења омогућује комплетно сагледавање те сложене појаве. Тако теорија, историја и критика превођења чине неку врсту транслатолошког троугла (Јанићијевић, 1999: 66). У њему посебан значај има критика превођења, с обзиром на то да је на пола пута између две крајности преосталих елемената троугла, те да спаја теорију и праксу превођења, сводећи се тако на комплексну активност од изузетног значаја за озбиљније вредновање и сагледавање преводилачке делатности у ширем културном или књижевноисторијском контексту и развоју преводне књижевности. Критика превођења је заправо и јасан облик коректива теорије.

\section{2. Српска преводна књижевност и критичка рецепција романа Пе- дро Парамо}

Хуан Рулфо (Juan Rulfo, 1918-1986) један је од најутицајнијих мексичких писаца XX века, а убраја се и у најзначајније обновитеље мексичке прозе и представнике тзв. магичног реализма (realismo mágico). У његовом свеукупном делу препознаје се снажан утицај Фокнера, али и мексичке књижевне традиције и националног фолклора. Оставио је неизбрисив траг у хиспаноамеричкој књижевности иако његов опус обухвата свега неколико дела, међу којима се издваја збирка приповедака Долина у пламену (El llano en llamas, 1953) и роман Педро Парамо (Pedro Páramo, 1955). ${ }^{1}$ У средишту Рулфовог књижевног опуса су усамљени појединац, лични немири и преокупације обичног човека, као и неретко тежак и сложен живот у мексичкој равници (Дицков, 2016: 198).

Роман Педро Парамо, сматра Љиљана Павловић Самуровић (1993: 694), одиграо је важну улогу у настајању и развоју специфичног тока мексичке и савремене хиспаноамеричке књижевности који је назван „магичним реализмом“. Роман се бави тематиком која је типична за овог мексичког приповедача: тежак живот пун изазова и проблема у сиромашним мексичким селима за време револуције ${ }^{2}$ и у постреволуционарном периоду. И у овом роману, али и у другим приповестима, Рулфо непрестано супротставља живот и смрт, прошлост и садашњост, а ликови се крећу у конкретним просторним координатама и говоре специфичним језиком: локалним (пре свега због дијалекатске обојености) и универзалним (услед изражавања страха пред животом и пред смрћу), стопљеним у јединствену и оригиналну целину, која чини овог писца једним

1 Рулфо је написао и кратки роман Златни петао (El gallo de oro, 1980), постхумно му је објављена збирка поезије и лирске прозе под насловом После смрти (Después de la muerte), а никада није завршио роман Кордиюери (La Cordillera).

2 Мексичка револуција (шп. Revolución mexicana) је појам који подразумева и односи се на политичка превирања, бројне пучеве и грађанске сукобе у Мексику који су трајали од 1910. до 1920. године. 
од најоригиналнијих приповедача новог хиспаноамеричког романа. Дело је доживело велики број издања како у Мексику тако и широм света, преведено је на више десетина језика, критика је јединствена у најпозитивнијим оценама, а урађене су и филмске и позоришне адаптације (Pavlović Samurović, 1993: 696). Ипак, роман је у први мах наишао на неразумевање или је пак збунио локалне књижевне критичаре, с обзиром на то да је Рулфо одустао од традиционалних приповедачких средстава и начина обраде тема о Мексичкој револуцији и блиском историјском периоду, одбацујући класичну хроничност догађаја као и реалистичку и документарну повезаност с конкретним историјским еквивалентима (Oviedo, 2005: 69). Како је време пролазило, роман Педро Парамо је постао предмет различитих, врло занимљивих и иновативних тумачења. Стога је важна била промена критичке перспективе коју су заузимали књижевни стручњаци широм света, односно интерпретација романа у светлу универзалних вредности и судова, повезујући срж и суштину дела с проблемом духовне дезоријентисаности савременог човека. Иако се не искључују ни другачије интерпретативне перспективе, основа и заједнички именитељ сваког критичког проматрања овог романа јесте егзистенцијализам и стварање специфичног и јединственог митског света (Shaw, 2008: 165).

У српској преводној књижевности роман Педро Парамо превођен је двапут. Први превод сачинио је Радоје Татић 1966. године у издавачком предузећу „Нолит“3, други Душка Радивојевић 2004. године при издавачкој кући „Рубикон“, а 2006. године „Градац“ и Фонд „Радоје Татић“ објавили су Рулфова Сабрана дела, која садрже и превод овог романа, али и приповедака из збирке Долина у пламену, у преводу Радоја Татића и Гордане Ћирјанић. Издавачка кућа „Дерета“ је верзију превода сабраних дела истих преводилаца објавила у свом издању из 2017. године.

Први превод на српски језик романа Педро Парамо објављен је 11 година након објављивања оригиналног дела, и очигледно је део шире позитивне, а испоставиће се и визионарске тенденције наших преводилаца тога времена, да српској и тада југословенској публици понуде дела актуелних писаца, посебно новог хиспаноамеричког романа, који се развија и заокупља пажњу књижевне јавности широм света. Хуан Октавио Пренс (1985: 450) истиче да је први превод романа Педро Парамо на српски (српскохрватски) језик остао у сенци објављених превода других хиспаноамеричких писаца у нашој средини, те да критичке осврте можемо пронаћи тек у годинама и деценијама које ће уследити, кад је јасно у ком смеру се књижевност Хиспанске Америке развија и какав ће траг оставити у контексту светске књижевности. Ретки текстови посвећени овом роману или његовом аутору биће информативне природе, углавном с намером да се други хиспаноамерички књижевници представе нашој средини, а Рулфо и његово дело искористе у узгредном компаративном контексту.

3 У оквиру овог издања објављен је и превод четири приповетке из збирке Долина у пламену: „Лувина“, „Долина у пламену“, „Анаклето Моронес“ и „Талпа“. 
Прво издање превода садржи и предговор у виду два пропратна текста под насловом „Хуан Рулфо“ Радоја Татића (1966: 9-11) и „Хуан Рулфо и модерни мексички роман“ Хуана Октавија Пренса (1966: 12-21). Први текст је општег карактера, у којем преводилац представља писца, његов књижевни опус, као и основне одлике свеукупног стваралаштва. Од великог је значаја централни део овог текста јер доноси кратку анализу садржине романа, функције ликова, основних наратолошких и текстолошких одлика, с посебним освртом на иновативност и оригиналност мексичког аутора у ширем контексту савремене мексичке прозе. Други уводни текст, обимнији и амбициознији, читаоцима омогућава темељнији увид у контекст развоја књижевности и романа о Мексичкој револуцији. Хуан Октавио Пренс у првом делу текста даје књижевноисторијски и критички преглед стваралаштва репрезентативних мексичких књижевника чија дела спадају у тзв. романе о Мексичкој револуцији: Маријана Асуеле (Mariano Azuela), Мартина Луиса Гусмана (Martín Luis Guzmán) и Xосеа Pубена Ромера (José Rubén Romero). Посебно треба нагласити објективност у оцени развоја ове врсте мексичког романа, будући да долази до јасне еволуције, од почетног одушевљења историјским променама до разочарања и доминације натуралистичких описа последицаิ револуције и изневерених идеологија које се могу ишчитавати из презентних текстова. Најдрагоценији део текста у светлу критичке рецепције романа садржи низ озбиљних оцена и елемената књижевноисторијске валоризације, која раније није могла бити понуђена читаоцима на нашим просторима. Пренс, као „идеални читалац“, врсни познавалац хиспаноамеричке књижевности, сада у улози обавештеног и компетентног критичара $и$ књижевног историчара, представља све важне иновативне елементе дела, посебно се бавећи питањима новог облика реализма, наративним техникама, напуштањем линеарне структуре, специфичним временским и просторним координатама, исцепканим приповедачким плановима, као и обрадом историјскогеографских података на тај начин да се преузима само ехо реалних података како би се направио јединствен митски свет Комале, мексичког градића у којем на различитим нивоима обитавају ликови романа. Коначно, аутор овог текста, својим умешним анализама у значајној мери доприноси проширењу будућих рецепцијских хоризоната домаћих читалаца и поштовалаца хиспаноамеричке књижевности, сврставајући Рулфа у ред савремених класичних романописаца, уз бројне већ познате или касније афирмисане писце светске књижевности.

Издање другог превода романа Педро Парамо, преводитељке Душке Радивојевић, које се појавило у првој деценији XXI, када настаје прави бум у области превођења са шпанског језика у српској културној средини, садржи кратак уводни текст који је потписан иницијалима „Т. А.“. Чини се да текст доприноси намери да се српски читалац обавести о основним видовима стваралаштва аутора, премда ни садржајем ни референцама не узима у обзир постојећу грађу о овом корпусу мексичког романа у нашој средини. Текст садржи низ информација и кратких осврта на развој оригиналне рулфовске естетике романа, на елементе магичног реализма, али и на ширу слику настанка дела, пропуштену 
кроз призму друштвених и историјских околности Мексичке револуције и њених последица. Посебно су занимљиви биографски увиди, сведочанства и цитати, којима су поткрепљени документарни вид дела, извор инспирације писца за настанак овог романа и идејна конструкција, о којој ретко можемо читати у текстовима објављеним на српском језику. На крају проналазимо позитивну и синтетичку оцену овог важног дела, која аутору / ауторки служи да представи критички капацитет и умеће у оваквој врсти књижевноисторијског вредновања:

Svojom jedinstvenom narativnom tehnikom i tekstualnom građom, roman Pedro Paramo daje mnogo bolji uvid u taj deo meksičke istorije nego neke objektivne studije; on uranja čitaoca u svet kontradikcija, u borbu s prošlošću koja još nije iščezla i sadašnjošću oblikovanu silama izvan naše moći i uticaja. (T. A., 2004: 7)

Уводни текст Радоја Татића из првог издања превода романа прештампан је и објављен и у савременом издању превода „Сабраних дела“ из 2006. године, али од веће су важности за критичку рецепцију два нова текста представљена српској публици: Поговор Хуана Октавија Пренса под насловом „Педро Парамо, врхунац и раскид у исти мах“ (2006: 221-226), претходно написан на шпанском језику, који је за ову прилику превела Гордана Ћирјанић; али и „Напомена уз ово издање“ (2006: 227). У уводним одељцима првог текста Пренс детаљно разматра и проблематизује контекст настанка Рулфовог романа, позивајући се на биографске цртице и сведочења романописца о природи писања и теоријског разматрања романескне грађе која ће кроз стваралачки процес тек бити конкретизована. Такође, подробно се бави и књижевноисторијским контекстом настанка овог романа, посебно истичући све иновативне елементе и неку врсту револуционарног приступа који заузима Рулфо. Осим јединствених и оригиналних елемената дела, у овом критичком тексту Пренс разматра и однос постојеће традиције хиспаноамеричке прозе и Рулфовог романа. Наглашава да су оригиналне наратолошке и поетолошке поступке користили и други писци хиспанских земаља иако никад на начин на који то чини мексички приповедач, који разлаже стварност правећи од њених елемената јединствени $и$ непоновљиви мозаик, који се може ваљано сагледати и разумети тек након три читања дела. Чини се да Пренс у овом језгровитом тексту доноси озбиљну и темељну анализу дела из различитих перспектива, а оцена коју даје позитивна је и у складу с компетенцијама и искуством једног песника и познаваоца хиспаноамеричке књижевности.

У кратком непотписаном тексту на страни 227 под насловом „Напомена уз ово издање“, читалац добија важне информације о природи преводне рецепције стваралаштва Хуана Рулфа и о његовом присуству у српској култури. Истиче се вредност првог превода романа Педро Парамо из 1966. године, који је „од самог појављивања књиге сматран узоритим, пре свега због његовог стила и истанчане језичке културе преводиоца“. На таласу позитивне рецепције првог превода 
овог романа код нас, преводитељка и списатељица Гордана Ћирјанић желела је да овом преводу подари ново рухо, те је урадила редакцију постојећег текста након четири деценије, а затим је и превела преостале приповетке збирке Долина у пламену, сачинивши тако „Сабрана дела“ Хуана Рулфа први пут на српском језику. Тако су постигнута два циља: одато је признање изузетном и вредном преводу Радоја Татића, а истовремено су српски читаоци у једном тому могли да читају целокупно дело мексичког приповедача, преведено с модерног и комплетног изворника.

За сада последње издање превода романа Педро Парамо, али и збирке Домина у пламену, објављено је 2017. године у издавачкој кући „Дерета“, а посреди је поново редакција превода Радоја Татића и придружених приповедака, чију редакцију и превод потписује Гордана Ћирјанић. У овом минуциозно припремљеном издању проналазимо уводни текст професора Далибора Солдатића, под насловом „Хуан Рулфо и зачарани круг историје“ (2017: 5-13), који делимично, по речима самог аутора, представља прерађену верзију текста „Педро Парамо - повест о неуспешном трагању“, објављеног 2006. године у Београдском књижевном часопису (бр. 2). На први поглед посреди је једноставан и структурно омеђен текст, сачињен по тематски дуалном обрасцу збирке Долина у пламену и романа Педро Парамо. Солдатић читаоца постепено уводи у књижевни опус Хуана Рулфа, а конкретна дела само су повод за илустрације и практичну демонстрацију свега што чини особеност прозе мексичког писца. Осим о друштвено-историјском контексту и значају Мексичке револуције у развоју мексичке књижевности XX века, аутор пише о важним наратолошким елементима и карактеристикама, поредећи Рулфова дела с другим делима хиспаноамеричких писаца епохе. Читалац проналази у овом тексту и елементе детаљне анализе садржине, ликова, просторно-временских одредница, пре свега романа Педро Парамо, а посебно треба истаћи и одељак посвећен успеху романа и његовој критичкој рецепцији у Мексику и широм света. Чини се да управо на тим местима имамо прилику да спознамо значај превођења овог дела на српски језик, али и да се упознамо с бројним особеностима књижевноисторијског карактера, које уз лично читалачко искуство могу допринети не само стварању комплетније слике о стваралаштву Хуана Рулфа, већ и о развоју савремене хиспаноамеричке прозе. Далибор Солдатић, као искусни хиспаниста и професор хиспаноамеричке књижевности, овим језгровитим текстом даје изузетно значајан допринос критичком проматрању најважнијих видова Рулфовог дела, а уједно позитивно оцењује и објективно вреднује значај романа Педро Парамо не само у изворном, хиспаноамеричком контексту, већ и у нашој, као и у другим националним преводним књижевностима.

На основу досадашње анализе критичких и књижевноисторијских текстова можемо закључити да се критичка рецепција стваралаштва Хуана Рулфа у српској културној средини појављује већ у годинама након објављивања првог превода романа Педро Парамо. Међутим, у претходних 40 година сфера интересовања за Рулфов роман биће проширена и на академску и научну филолошку 
средину, те у наставку разматрамо и тај део истраживачког корпуса, који подразумева неколико чланака објављених у часописима, зборницима и другим стручним или научним публикацијама. ${ }^{4}$

Уколико овај корпус посматрамо у хронолошком следу, за критичку, академску и читалачку рецепцију новог хиспаноамеричког романа у Србији значајан је текст Далибора Солдатића под насловом „Хиспаноамерички роман данас“, објављен у тематском броју часописа Дело 1978. године. ${ }^{5}$ Иако је посреди текстуални прилог најопштијег карактера, информативне намене не би ли српски и југословенски читалац стекао подробнију и ширу слику о новим токовима хиспаноамеричке књижевности, у завршним разматрањима наилазимо на објективну и на стварности утемељену оцену да су присуство и рецепција „бума“ хиспаноамеричког романа закаснели процеси у југословенској средини, с обзиром на то да се у другим културама у том тренутку већ више од деценије преводи, критички проматра и кроз уметничку рецепцију у националним књижевностима прихвата нови хиспаноамерички роман. Осим неких најпознатијих дела Астуријаса, Гарсија Маркеса, Кортасара, Варгас Љосе, Фуентеса или Рулфа, објављених у претходним деценијама и у преводима на српски (српскохрватски) језик, највећи део новог хиспаноамеричког романа и даље је био непознат локалној културној средини, а преведена дела су прошла незапажено. Један од могућих разлога које аутор текста наводи јесте и изостанак медијске подршке, критичких приказа у релевантним културним додацима и књижевним часописима, недостатак стручњака за ову област код нас, импровизација у сфери преводилаштва и непознавање основних процеса и развоја савремене хиспаноамеричке књижевности (Soldatić, 1978: 41).

Текст Марице Јосимчевић под насловом „Педро Парамо: роман грађен шаптајима“ (2004: 101-106) резултат је умешног, критичког и компетентног читања Рулфовог романа. Упркос форми критичког осврта или есеја, без пожељног критичког апарата, овај текст у великој мери синтетички представља поетику романа Хуана Рулфа, али и специфичан однос писца према материји о којој се приповеда. Посебан значај у тексту има детаљна тематско-мотивска анализа дела, те контекстуализација тема̂ љубави, живота и смрти, које су иако универзалне место пронашле и у овом роману, а обрађене су на оригиналан начин и у складу с поетиком магичног реализма. Кроз садржинску и структурну анализу

4 Међу прегледима хиспаноамеричке књижевности на српском језику, који садрже и одреднице посвећене стваралаштву Хуана Рулфа, посебно место заузимају Лексикон хиспаноамеричке књижевности Љиљане Павловић Самуровић (Београд: Савремена администрација, 1993) и Хиспаноамеричка књижевност (ОӘ постмодернизма до постбума) Весне Дицков (Београд: Филолошки факултет, 2016). Реч је о лексиконској одредници (Павловић Самуровић, 1993: 692-698), односно одељку текста (Дицков, 2016: 197-201) општег, информативног типа, који су намењени не само студентима хиспанистике, већ и ширем кругу заинтересованих читалаца и поклоника савремене хиспаноамеричке књижевности.

5 Приређена тематска свеска часописа садржи ауторске текстове приређивача Бранка Анђића и Далибора Солдатића, али и бројне критичке и књижевноисторијске текстове махом латиноамеричких писаца и аутора, који су за ову прилику преведени на српски (српскохрватски) језик. Текстови не садрже конзистентну или конкретну анализу процеса преводне или критичке рецепције стваралаштва Хуана Рулфа, већ тек узгред наводе његова дела, као илустрацију представљања и анализе ширег контекста развоја и постојања новог хиспаноамеричког романа и прозе. 
ауторка представља важне елементе романа Педро Парамо, а посебно анализира одлике ликова и наратолошке специфичности дела, исцепкане приповедачке планове, фрагментарност структуре, временске и просторне координате, које својом променљивошћу и покретом утичу на развој радње и условљавају делање ликова. На крају текста проналазимо и ауторкину синтетичку оцену романа, у којој истиче несумњиво трајне и универзалне вредности, препознате и у текстовима савремене књижевне критике:

При сваком новом читању Педра Парама извиру слојеви значења које као да раније нисмо приметили - што је увек карактеристика дела која су писана језиком симбола и слика; но, оно што овај роман издваја, ма о којој литератури у свету да је реч, свакако је маестрално изведена саобразност живих и мртвих, од чијих је шаптаја изграђена најсуптилнија романескна структура. (Јосимчевић, 2004: 106)

Далибор Солдатић у тексту под насловом „Педро Парамо - повест о неуспешном трагању“ (2006: 215-219) читаоцима на само неколико страница поједностављено разлаже најважније елементе пре свега поетике књижевног стваралаштва Хуана Рулфа, а затим и истакнуте оригиналне одлике романа Педро Парамо. У том смислу, Солдатић кроз већ изграђену перспективу „идеалног читаоца“ поступно осветљава неколико видова романа, а пре свега ликове и њихове међусобне односе, време и простор у делу, митски свет дела, као и специфичан романескни универзум мексичког писца, у којем важе посебна правила и развија се свет паралелне стварности, по већ утврђеним обрасцима магичног реализма. На крају, у краткој оцени романа, Солдатић у неколико речи одговара на суштинско питање шта то чини овај роман великим делом мексичке, хиспаноамеричке и светске књижевности, истичући да је то „пре свега унутрашња строгост и прецизност структуре а затим симболично значење његовог погледа на свет" (Солдатић, 2006: 219).

Један од ретких текстова и усамљени пример научне рецепције Рулфовог романа код нас јесте управо још један текст Далибора Солдатића под насловом „Мексички роман и историја“, објављен 2011. године у часопису Наслеђе (бр. 18 - Шпански и хиспаноамерички роман: језик, идеологија, дискурс, истоpuјa, поетика). У овом чланку Солдатић се бави присуством видова историје и њеним преобликовањем у књижевни дискурс два репрезентативна дела из корпуса новог хиспаноамеричког романа: Педро Парамо Хуана Рулфа и Terra Nostra Карлоса Фуентеса. Према речима аутора чланка, Рулфов роман је „један од најбољих примера обнављања тог културног, колективног и појединачног памћења“ (Солдатић, 2011: 291). Памћење се повезује с традицијом, а историјски процеси сматрају узроцима тешког живота локалног становништва, које живи у непрестаној спирали насиља и специфичног облика варварства. Посебну пажњу у овој Солдатићевој анализи завређују питања колективног идентитета, историјског памћења, традиције, свакодневице и сукоба дискурса 
победника и поражених. Тако роман добија једну универзалну димензију, с озбиром на то да је кроз причу и историју о Педру Параму испричана повест о Мексику и да су представљене основе једне националне епопеје (Солдатић, 2011: 292).

У академским оквирима још увек нема озбиљније рецепције романа Педро Парамо, а прве кораке интеркултурног дијалога и рецепције у нашој академској средини кроз наставни процес остварују студенти хиспанистике на Филолошком факултету у Београду, Филолошко-уметничком факултету у Крагујевцу и на Филозофском факултету у Новом Саду. У том смислу, треба издвојити допринос рецепцији који је дала Тијана Шестовић, одбранивши 2019. године на Филолошком факултету мастер рад под насловом „Педро Парамо и Долина у пламену и њихови примењени аспекти у универзитетској настави хиспанистике“, под менторством проф. др Анђелке Пејовић. У овом раду су обрађени најважнији елементи друштвено-историјског и књижевноисторијског вида стваралаштва Хуана Рулфа, а понуђени су и дидактички модели који могу бити корисни у процесу обраде ове методске јединице на универзитетском нивоу.

Ретки прикази или новинске нотификације о превођењу и објављивању романа Педро Парамо или пак о свеукупном стваралаштву Хуана Рулфа ни су с намером да информишу најшири круг потенцијалних читалаца о новим токовима хиспаноамеричке прозе и о преводилачкој делатности у нашој средини, а углавном су настајали током 2006. године, подстакнути објављивањем „Сабраних дела“ у издавачкој кући „Градац“. Међутим, чини се да нису имали већи одјек нити су допринели даљем усмерењу рецепције и саображавању овог корпуса новије хиспаноамеричке књижевности нашој културној средини. Ипак, значајан догађај у процесу приближавања стваралаштва Хуана Рулфа српској културној средини била је тертулија поводом стогодишњице од рођења писца, одржана у Институту Сервантес у Београду 14. новембра 2017. године. Осим Александра Шурбатовића, уредника у издавачкој кући „Дерета“, и Бојане Ковачевић Петровић, хиспанисткиње, преводитељке и доценткиње на Филозофском факултету у Новом Саду, у омажу Рулфовом делу учествовали су и студенти хиспанистике, доприносећи представљању и анализи разних видова не само романа Педро Парамо, већ и свеколиког дела писца у мексичком, хиспаноамеричком и светском контексту. Овим догађајем најављено је објављивање најновијег издања превода „Сабраних дела“ Хуана Рулфа у издању издавачке куће „Дерета“.

Књижевни утицаји укупног Рулфовог дела или пак романа Педро Парамо на српске писце друге половине XX и првих деценија XXI века нису били предмет изучавања српске научне и академске средине, а не изненађује чињеница да је фокус наших истраживача и хиспаниста по правилу био на стваралаштву и

6 Vid. Остојић 1983, Врбавац 2006, Milenković 2006, Пејчић 2006. 
утицајима најпознатијих и најфреквентнијих аутора хиспаноамеричког „бума“, попут Кортасара, Фуентеса, Варгас Љосе и Гарсија Маркеса (Kovačević Petrović, 2016: 155). Стога би један од императива и фокуса даљих истраживања хиспаниста требало да буде управо конзистентна и систематска анализа утицаја свеколиког дела Хуана Рулфа у поетикама и конкретним делима писаца српске књижевне средине.

\section{3. Роман Педро Парамо у српским преводима: прилог упоредној тра- дуктолошкој анализи}

У теорији, први корак у компаративној анализи различитих верзија превода једног књижевног дела требало би да буде утврђивање изворника који је коришћен при преводу. У пракси, овај прелиминарни део анализе најчешће није захтеван задатак и готово да је сведен на пуку формалност јер су, макар у савременој књижевности, ређи случајеви да једном објављено дело претрпи значајније интервенције које би ишле даље од исправљања ерата, незнатних промена интерпункције или графичких карактеристика текста. А када до таквих измена дође, то се обично адекватно назначи у пропратном тексту. Међутим, када је реч о роману Педро Парамо ситуација је нешто сложенија. Наиме, објављивањем овог дела 1955. године Хуан Рулфо није ставио тачку на рад на свом једином роману. Наставио је да обликује и дотерује текст уносећи измене у потоња издања све до верзије из 1981. године која се сматра коначном (Volek, 1990: 38). Најзначајнија одступања од оригиналног текста забележена су у петом издању из 1964. године - више од две стотине интервенција (Robles, 1982: 106). Иако већи део не утиче у знатнијој мери на читаочеву перцепцију дела, темељније модификације текста као што су различита конфигурација параграфа, додавање нових или изостављање постојећих речи, па и читавих реченица, синтаксичке транспозиције, модификовање глаголских времена или вида глагола мењају читаочеву реакцију на текст и, што је за анализу превода овог дела на српски језик најважније, питање издања које је преводилац користио претварају у императив. Захваљујући студији Умберта Роблеса (1982: 106-116) која се бави проучавањем различитих издања романа Педро Парамо, а у којој су наведени примери најрелевантнијих промена које се појављују у петом издању, могли смо да утврдимо да су Радоје Татић и Душка Радивојевић, као и Гордана Ћирјанић, која је редиговала први превод романа на српски језик, користили исту варијанту текста. Као полазна основа послужили су нам делови текста код којих су поједине реченице, присутне у оригиналном и потоњим издањима, у петом изостављене. Такав је случај са следећим одломком чија последња реченица (обележена курзивом) не постоји у преводу на српски језик, што указује на то који су изворник преводиоци користили. Упркос различитим преводилачким решењима, јасно је да је реч о истом тексту: 


\begin{tabular}{|c|c|c|}
\hline $\begin{array}{c}\text { Изворник } \\
\text { (Rulfo, 2011: 219) }\end{array}$ & $\begin{array}{c}\text { Радоје Татић } \\
\text { (Rulfo, 1966: 55) }\end{array}$ & $\begin{array}{c}\text { Душка Радивојевић } \\
\text { (Rulfo, 2004: 38) }\end{array}$ \\
\hline $\begin{array}{l}\text { Quizá tu hermana esté } \\
\text { nostálgica por su regreso. } \\
\text { - ¿A quién le hablas? } \\
\text { - A ti. } \\
\text { - Mejor, vámonos, muchachos. } \\
\text { Hemos trafagueado mucho y } \\
\text { mañana hay que madrugar. } \\
\text { Y se disolvieron como } \\
\text { sombras. } \\
\text { - iDile que no llore, que aquí } \\
\text { me tiene a mí! - Me saludas a } \\
\text { la tuya - le contestaron }\end{array}$ & $\begin{array}{l}\text { Možda je tvoja sestra setna i } \\
\text { priželjkuje njegov povratak. } \\
\text { - Kome ti to? } \\
\text { - Tebi. } \\
\text { - Bolje da idemo, momci. Danas } \\
\text { smo se dosta nahodali, a sutra } \\
\text { treba poraniti. } \\
\text { I raziđoše se, kao senke. }\end{array}$ & $\begin{array}{l}\text { Možda je tvoja sestra } \\
\text { nostalgična zbog njegovog } \\
\text { povratka. } \\
\text { - Kome ti to govorišs? } \\
\text { - Tebi. } \\
\text { - Bolje da podemo, momci. } \\
\text { Mnogo smo radili, a sutra treba } \\
\text { poraniti. } \\
\text { I rastopiše se kao senke. }\end{array}$ \\
\hline
\end{tabular}

Већ у овом кратком одломку назиру се разлике у концепцији превода. Радоје Татић склонији је нешто слободнијем тону или адаптацијама у ситуацијама када процени да ће такав приступ бити најпогоднији, било зато што тиме оставља мање простора за погрешну интерпретацију текста чинећи га разумљивијим читаоцу, било зато што сматра да ће на тај начин постићи бољи естетски ефекат. Тако у реченици: „Моžda je tvoja sestra setna i priželjkuje njegov povratak“, Татић придев “nostálgico” не преводи другим придевом већ описно, како би нагласио садржај речи, истовремени осећај туге и жеље за поновним сусретом. С друге стране, Душка Радивојевић се радије опредељује за дословнија решења: „Možda je tvoja sestra nostalgična zbog njegovog povratka“. Као и у реченици: “Ү se disolvieron como sombras”, где бира основно значење глагола “disolver“ (pacтопити, растворити, распршити) те реченицу преводи: „I rastopiše se kao senke“, насупрот Татићевом решењу где се прибегава нормализацији: „I raziđoše se, kao senke“. Исти приступ превођењу уочава се и у осталим реченицама из одломка, као што је: “АA quién le hablas?” која у преводу Душке Радивојевић гласи: „Коте ti to govoriš?“, док Радоје Татић реченицу прилагођава говорном регистру и с тим циљем изоставља глагол „говорити“: „Коme ti to?“

Редакција превода Гордане Ћирјанић не пружа довољно материјала да би се могла коментарисати њена концепција превода, јер ако је судити по броју измена, ограничила се само на оно што је по њеним критеријумима било нужно, пре свега лексичке корекције. Прикладно су замењене поједине речи које је Татић неправилно превео или наведене оне које је из неког разлога изоставио попут “puesto” (Rulfo, 2011: 206) / „tezga“ (Rulfo, 2017: 103) за коју Татић не даје директан превод (Rulfo, 1966: 123) или “trote rebotado de los burros” (Rulfo, 2011: 194) / „topot kopita magaraca i mazgi“ (Rulfo, 1966: 27), замењено са „topot magarećih kopita“ (Rulfo, 2017: 18). Видљива је намера Гордане Ћирјанић да 
на одређеним местима текст учини поетичнијим, те Татићев превод реченице “Entonces el cielo se adueñó de la noche” (Rulfo, 2011: 219) / „Onda je nebo ovladalo čitavom noći“ (Rulfo, 1966: 56) у њеној редакцији гласи: „Onda je nebo zaposelo noć“ (Rulfo, 2017: 44). Поједине интервенције не делују оправдано. Упркос повременим омашкама у преводу, Радоје Татић показује одлично разумевање ширег контекста и онога што Рулфо намерава да изрази својом прозом; у сваком тренутку има у виду читаво дело и судбине ликова. Тако, на пример, речи које изговара Долорес Пресијадо пошто је Педро Парамо запроси: “Gracias, Dios mío, por darme a don Pedro" / "Aunque después me aborrezca” (Rulfo, 2011: 24), упркос томе што акузатив из првог дела реченице преводи дативом: „Hvala ti, moj Bože, što si me dao don Pedru“, Татић исправно преноси најзначајнију информацију у овом одломку: „Makar me posle i mrzeo“ (Rulfo, 1966: 67). Долорес прихвата брак, почаствована што је тако моћан човек одабрао баш њу, али и срећна јер тај брак значи и помак на друштвеној лествици, макар је касније и презрео, што даље у роману сазнајемо да се заиста $и$ догодило. Ћирјанић превића судбину овог лика те реченицу преводи: „Makar posle i prezrela sebe“ (Rulfo, 2017: 54). На истоветан начин ову реченицу протумачила је и Радивојевић: „Hvala milom bogu da pođem za don Pedra“ / „Makar kasnije samu sebe prezrela“ (Rulfo, 2004: 49). Heприкладних интервенција има и на лексичком нивоу, тачан превод "culebras de agua” (Rulfo, 2011: 206) / „vodene zmije“ (Rulfo, 1966: 40) преиначен је погрешно y „gradonosni oblaci“ (Rulfo, 2017: 30).

Преношењу реалија и елемената својствених мексичком културном контексту преводиоци различито приступају мада не у потпуности доследно. Душка Радивојевић прибегава транскрипцији појмова за које не постоје еквиваленти у српском језику, означава их наводницима и њихово значење наводи у фусноти, о томе говори и њихов број, 37 фуснота насупрот Татићевих 7. Најчешће су то појмови који означавају флору, фауну, храну или пиће. Одређене појмове за које сматра да су блиски домаћем читаоцу транскрибује не издвајајући их графички у тексту, као реч „тортиља“ (Rulfo, 2004: 67). Међутим, уколико постоје барем делимични еквиваленти тих појмова, онда их преводи: "frijoles" (Rulfo, 2011: 284) / "pasulj“ (Rulfo, 2004: 112), “maguey” (врста агаве) (Rulfo, 2011: 274) / „agava“ (Rulfo, 2004: 101), “rebozo” (врста женског шала) (Rulfo, 2011: 198) / „marama“ (Rulfo, 2004: 14). Код Татића је уочљивији труд да реалије, нарочито оне из свакодневног живота или културно маркиране појмове неутралнијег значења прилагоди српском језику, но то чини с променљивим успехом; исправно преводи поједине појмове као што је “сесina” (Rulfo, 2011: 244) / „suvo meso“ (Rulfo, 1966: 86), али има омашки: "maguey" (врста агаве) (Rulfo, 2011: 274) преводи као „katus“ (Rulfo, 1966: 123) или "pulque” (алкохолно пиће од агаве) (Rulfo, 2011: 274) као „rakija od kaktusa“ (Rulfo, 1966: 123). Нисмо сигурни колико је оправдана одлука преводилаца да се реч “correcaminos” (птица тркачица) (Rulfo, 2011: 197) преведе неологизмом „trčiputko“ (Rulfo, 2004: 13) или „pustahija“ (Rulfo, 1966: 29). Идентична необична одлука преводилаца указује да је Душка Радивојевић приликом превођења имала у виду решење првог преводиоца романа. 
Властита имена, чак и кад поседују симболичка значења, нису превођена, осим појединих надимака, мада Радивојевић наводи њихова значења у фусноти. Занимљива су решења која су преводиоци дали за надимак “Saltaperico" (Rulfo, 2011: 206): код Татића је то „Реtarda“ (Rulfo, 1966: 40), у редакцији превода „Skakavac“ (Rulfo, 2017: 31), а код Радивојевић „Skočiperica“ (Rulfo, 2004: 24), peшење којим је успела да постигне и звучну сличност. Највећи број топонима се транскрибује, отуда се називи места попут “Los Confines" (Rulfo, 2011: 236) или “Media Luna” (Rulfo, 2011: 243) у српским преводима појављују као „Konfines“ (Rulfo, 1966: 77; Rulfo, 2004: 58) и „Medija-luna“ (Rulfo, 1966: 80) / „Medija Luna“ (Rulfo, 2004: 61), док је за друге понуђен превод, попут “Puerta de Piedra” (Rulfo, 2011: 236) / „Kamena vrata“ (Rulfo, 1966: 138). Хуан Октавио Пренс (1985: 49) као пример изузетно успешног превода топонима наводи поједина решења Радоја Татића, као што је назив локалитета у следећој реченици: “Me había topado con él en los «Encuentros», donde se cruzaban varios caminos” (Rulfo, 2011: 195) / „Sreo sam ga kod zapisa zvanog „Susreti“, gde se ukrštalo više puteva“ (Rulfo, 1966: 27). Душка Радивојевић исти топоним преводи као „Stecište“ (Rulfo, 2004: 11).

Посебно велики преводилачки изазов представљају две варијанте језика присутне у роману. С једне стране говорни језик богат мексиканизмима, обојен одређеним карактеристикама својственим области Халиско, деминутивима, аграматичким облицима, а с друге стране језик наратора, изузетно поетичан $и$ подједнако сложен за превод. У нараторским деловима Татић често једну поетску слику замењује другом, као у следећем примеру, где чуло укуса замењује мирисом, а метафоричку слику „испити ваздух“, нормализује у „удисати ваздух“: "Hay pueblos que saben a desdicha. Se les conoce con sorber un poco de aire viejo y entumido...” (Rulfo, 2011: 270) / „Ima sela koja zaudaraju na nesreću. Da bi se prepoznala, dovoljno je udahnuti malo njihovog starog i ustajalog vazduha..." (Rulfo, 1966: 119). Радивојевић преузима ово решење, али јачи глагол „заударати“ замењује блажим обликом „мирисати“: „Postoje sela koja mirišu na nesreću. Prepoznaju se kad se udahne malo njihovog starog i ustajalog vazduha..." (Rulfo, 2004: 97). Наклоњеност дословнијим решењима Душке Радивојевић покаткад даје реченице које делују неспретно срочене, као у следећем примеру, где до таквог утиска доводи понављање речи: "Y más allá, una línea de montañas. Y todavía más allá, la más remota lejanía” (Rulfo, 2011: 195) / „I još dalje, linija planina. I još dalje, najdalja daljina“ (Rulfo, 2004: 11). Татић овде нуди неупоредиво вештије решење: „Malo dalje, planine u nizu. A iza, još dalje, beskrajna daljina“ (Rulfo, 1966: 19). Стиче се утисак да Татић брижљивије врши одабир лексике, при чему повремено предност даје нешто архаичнијим облицима, попут речи „корбач“ (Rulfo, 1966: 61) уместо „бич“, но то чини ваљано, с мером и не оптерећује текст. Исти, нешто архаичнији тон, реченици даје превођење шпанског времена pretérito indefinido аористом, док се Душка Радивојевић у истим ситуацијама пре одлучује за перфекат.

Дијалекатски маркирани дијалози чине готово трећину романа Педро Парамо. Стилски су функционално употребљени, доприносе карактеризацији ли- 
кова и стварању атмосфере, али и условљавају понашање ликова, те је њихово адекватно превођење изузетно важно. Говор сељана из области Халиско специфичан је не толико по заступљености мексиканизама и лексике својствене том крају, колико по извесним синтаксичким обележјима, као што је ред речи у реченици који често одступа од стандардног, употреба идиома или пословица. У преводу на српски оба преводиоца се служе стандардним језиком, различитог нивоа колоквијалности. Поменуте различите концепције превода долазе до изражаја и у овом сегменту, те изреку којом се описује нечија шкртост "no darle el agua ni al gallo de la pasión” (Rulfo, 2011: 285), Татић не преводи, већ замењује другим изразом са сличним значењем „не дати ни богу тамјан“ (Rulfo, 1966: 137), задржавајући тако религиозну конотацију оригиналног израза, док Радивојевић изреку преводи исправно мада је донекле поједностављује: „не дати ни чашу хладне воде“ (Rulfo, 2004: 113). Експресивну лексику и псовке Радивојевић преводи експлицитније од Татића, као што је случај са реченицом "Para eso se necesita tener los riñones de este tamaño” (Rulfo, 2011: 252) / „Za to treba imati ovolika jaja“ (Rulfo, 2004: 76) / „Za to treba imati ovoliko srce“ (Rulfo, 1966: 96) или “Váyase al carajo” (Rulfo, 2011: 197) / „Ma, nosite se! (Rulfo, 2004: 13)“, где Татић прибегава еуфемизму: „Idite do đavola!“ (Rulfo, 1966: 29).

Већ и пажљивијим читањем превода овог великог мексичког романа на српски језик јасно се уочавају приступи превођењу његових преводилаца, као и језичка средства која су користили за изражавање изворног текста, што спроведена упоредна анализа и показује. У преводу Радоја Татића наглашеније су формалне разлике између језика нарације и говорне варијанте језика, а проблеме које овај потоњи регистар намеће преводиоцу он решава спретније, што резултира природнијим и уверљивијим дијалозима. У преводу Душке Радивојевић ове две варијанте језика су мање диференциране, а склоност ка дословнијем превођењу не доводи увек до жељеног учинка. Иако се стиче утисак да Татић успешније интегрише читаоца у дело, у оба превода он добија довољно информација неопходних за разумевање текста, а евентуалне омашке у преводу не утичу негативно на рецепцију дела. Вечито је питање да ли за преводиоца који преводи већ преведено дело оно представља олакшицу или додатни притисак и одговорност, посебно кад је у питању преводилац репутације Радоја Татића. У овом случају, можда би се до успешнијег учинка дошло уз мало већи отклон од првог превода. Такође, остаје утисак да у новом преводу нису у довољној мери надограђени поједини сегменти текста или поједина решења која у првом преводу због објективних друштвено-историјских ограничења остављају простора за побољшање.

\section{4. Закључак}

Хиспаноамеричка књижевност већ деценијама је добро позната нашој културној средини, а посебно књижевна остварења савремених писаца, припадника тзв. „бума“ новог хиспаноамеричког романа. Српска и југословенска културна средина постепено су се упознавале с новим токовима развоја хиспаноаме- 
ричке књижевности и то у првим годинама или деценијама након настанка ове групе дела, па можемо говорити чак о повлашћеном положају наше читалачке публике и културних посленика. Разлоге овом усклађивању са светским токовима и брзој реакцији домаће средине, спремне да се сусретне с књижевним делима јужноамеричког континента, треба тражити у визионарским и смелим напорима наших преводилаца, потом школованих хиспаниста, али и издавачких кућа, да на српском (српскохрватском) језику понуде наслове из још увек недовољно познате стране књижевности.

Наша културна средина и преводна књижевност бележе бројне успешне преводе дела најзнаменитијих савремених хиспаноамеричких писаца (X. Л. Борхес, К. Фуентес, Х. Кортасар, М. Варгас Љоса, итд.), али је јасно развијена и свест преводилаца и хиспаниста̂ о значају далеко ширег круга писаца, који су својим делом стварали темеље савремене хиспаноамеричке прозе и утицали на генерације писаца широм света, чија се дела данас након кратке временске дистанце већ сматрају класицима светске књижевности. У овом контексту треба посматрати и рецепцију стваралаштва Хуана Рулфа у српској културној средини и преводној књижевности. Након већ пола века преводне рецепције стваралаштва овог мексичког писца код нас, располажемо преводима „Сабраних дела“, а његов роман Педро Парамо преведен је двапут (Радоје Татић, 1966. и Душка Радивојевић, 2004. године), уз две редакције првог превода (2006. и 2017. године), објављене у оквирима озбиљних издања реномираних српских издавачких кућа.

Преводи и критички текстови који су их пратили резултат су јасне жеље преводилаца и(ли) хиспаниста и историчара хиспаноамеричке књижевности да домаћем читаоцу понуде основне информације о разним видовима стваралаштва мексичког писца и његових књижевних остварења. Након књижевнокритичке активности развијена је и озбиљнија академска и научна рецепција Рулфовог дела, као директна последица развоја српске хиспанистике у универзитетском контексту. Преводи романа Педро Парамо на српски језик, сачињени у складу с добром преводилачком праксом и традицијом у нашој средини, у највећој мери одражавају најбитније одлике оригиналног текста, верно преносе дух, амбијент, елементе романескне радње и све друге оригиналне видове дела. Мање преводилачке омашке, недоследности или упитна преводилачка решења, повремено присутна и у анализираним текстовима, не умањују квалитет превода и немају велики значај за процес рецепције овог романа у нашој културној средини.

\section{Литература}

Врбавац, J. (2007). Претеча магичног реализма - Хуан Рулфо, Сабрана дела (Градац, 2006) In J. Врбавац, Три и по (критике) (pp. 176-177). Нови Сад: Агора.

[Vrbavac, J. (2007). Preteča magičnog realizma - Huan Rulfo, Sabrana dela (Gradac, 2006) In J. Vrbavac, Tri i po (kritike) (pp. 176-177). Novi Sad: Agora] 
Дицков, В. (2016). Хиспаноамеричка књижевност (Од постмодернизма до постбума). Београд: Филолошки факултет.

[Dickov, V. (2016). Hispanoamerička književnost (Od postmodernizma do postbuma). Beograd: Filološki fakultet]

Јанићијевић, Ј. (1999). Кюижевни превод и преводна кюижевност. Београд: Идеа.

[Janićijević, J. (1999). Književni prevod i prevodna književnost. Beograd: Idea]

Јосимчевић, М. (2004). Педро Парамо: роман грађен шаптајима. Свеске, XV(71), 101-106.

[Josimčević, M. (2004). Pedro Paramo: roman građen šaptajima. Sveske, XV(71), 101-106] Манчић, А. (2010). Превод и критика. Београд: Институт за књижевност и уметност.

[Mančić, A. (2010). Prevod i kritika. Beograd: Institut za književnost i umetnost]

Остојић, Р. (1983). Шпанска награда аутору Педра Парама. Летопис Матице српске, 159(432), 5, 623-624.

[Ostojić, R. (1983). Španska nagrada autoru Pedra Parama. Letopis Matice srpske, 159(432), 5, 623-624]

Пејчић, Н. (21. април 2006). Сабрана дела Хуана Рулфа. Дневник: орган Народног фронта, год. 64, 6р. 21264, стр. 11.

[Pejčić, N. (21. april 2006). Sabrana dela Huana Rulfa. Dnevnik: organ Narodnog fronta, god. 64, br. 21264, str. 11]

Солдатић, Д. (2006). Педро Парамо - повест о неуспешном трагању. Београдски књижевни часопис, 2, 215-219.

[Soldatić, D. (2006). Pedro Paramo - povest o neuspešnom traganju. Beogradski književni časopis, 2, 215-219]

Солдатић, Д. (2011). Мексички роман и историја. Наслеђе, VIII(18) (Темат: Шиански и хиспаноамерички роман - језик, идеологија, дискурс, историја, поетика), 289-298.

[Soldatić, D. (2011). Meksički roman i istorija. Nasleđe, VIII(18) (Temat: Španski i hispanoamerički roman - jezik, ideologija, diskurs, istorija, poetika), 289-298]

Шестовић, Т. (2019). Педро Парамо и Долина у пламену, и юихови применени аспекти у универзитетској настави хиспанистике (необјављен мастер рад). Филолошки факултет, Београд.

[Šestović, T. (2019). Pedro Paramo i Dolina u plamenu, i njihovi primenjeni aspekti $u$ univerzitetskoj nastavi hispanistike (neobjavljen master rad). Filološki fakultet, Beograd]

Bugarski, R. (1981). Teorija prevođenja kao naučna disciplina. In Lj. Rajić (prir.), Teorija i poetika prevođenja (pp. 7-26). Beograd: Prosveta.

Volek, E. (1990). Pedro Páramo de Juan Rulfo: Una obra aleatoria en busca de su texto y del género literario. Revista iberoamericana, 150, 35-48. https://doi.org/10.5195/reviberoamer.1990.4668

Carbonell i Cortés, O. (1999). Traducción y cultura: de la ideología al texto. Salamanca: Ediciones Colegio de España.

Kovačević Petrović, B. (2016). El impacto del boom latinoamericano en los escritores serbios. Acta Hispanica, 21, 143-156. 
Milenković, I. (4. maj 2006). Rulfove sablasti. Vreme, br. 800. Dostupno preko: https:// www.vreme.com/cms/view.php?id=451740 [6.3.2021]

Napomena uz ovo izdanje. (2006). In H. Rulfo. Sabrana dela (Pedro Paramo, Dolina u plamenu). Preveli sa španskog R. Tatić i G. Ćirjanić. Čačak: Branko Kukić (Gradac)/ Beograd: Fondacija „Radoje Tatić“, 227.

Oviedo, J. M. (2005). Historia de la literatura hispanoamericana, Vol. 4 - De Borges al presente. Madrid: Alianza Editorial.

Pavlović Samurović, Lj. (1993). Rulfo, Huan. In Lj. Pavlović Samurović, Leksikon hispanoameričke književnosti (pp. 692-698). Beograd: Savremena administracija.

Prens, H. O. (1966). Huan Rulfo i moderni meksikanski roman. In H. Rulfo, Pedro Paramo (pp. 12-21). Prevod R. Tatić, predgovor R. Tatić i H. O. Prens. Beograd: Nolit.

Prens, H. O. (2006). Pedro Paramo, vrhunac i raskid u isti mah. In H. Rulfo, Sabrana dela (Pedro Paramo, Dolina u plamenu) (pp. 221-226). Preveli sa španskog R. Tatić i G. Ćirjanić. Čačak: Branko Kukić (Gradac)/Beograd: Fondacija „Radoje Tatić“.

Prenz, J. O. (1985). Pedro Páramo en Yugoslavia. Cuadernos Hispanoamericanos, 421423, 449-458.

Dostupno preko: http://www.cervantesvirtual.com/nd/ark:/59851/bmc3n2n2 [26.1.2021]

Robles, H. E. (1982). Variantes en Pedro Páramo. Nueva Revista de Filología Hispánica, 31, 106-116. https://doi.org/10.24201/nrfh.v31i1.2709

Sibinović, M. (1981). »Stvaraoci« i »teoretičari« (Razmišljanje o nekim starim i banalnim nedoumicama). In Lj. Rajić (prir.), Teorija i poetika prevođenja (pp. 27-43). Beograd: Prosveta.

Soldatić, D. (1978). Hispanoamerički roman danas. In Vavilonska biblioteka - Nova hispanoamerička književnost. Priredili B. Anđić i D. Soldatić. Delo, XXIV(8-9), 28-41. Soldatić, D. (2017). Huan Rulfo i začarani krug istorije. In H. Rulfo, Pedro Paramo, Dolina u plamenu (pp. 5-13). Prevod sa španskog R. Tatić i G. Ćirjanić. Beograd: Dereta.

Shaw, D. L. (2008). Nueva narrativa hispanoamericana-Boom. Posboom, Posmodernismo. Madrid: Cátedra.

T. A. (2004). Predgovor. In H. Rulfo, Pedro Paramo (pp. 5-7). Sa španskog prevela D. Radivojević. Novi Sad: Rubikon.

Tatić, R. (1966). Huan Rulfo. In H. Rulfo, Pedro Paramo (pp. 9-11). Prevod R. Tatić, predgovor R. Tatić i H. O. Prens. Beograd: Nolit.

Tatić, R. (2006). Predgovor. In H. Rulfo, Sabrana dela (Pedro Paramo, Dolina u plamenu) (pp. 7-8). Preveli sa španskog R. Tatić i G. Ćirjanić. Čačak: Branko Kukić (Gradac)/ Beograd: Fondacija „Radoje Tatić“.

\section{Извори}

Rulfo, H. (1966). Pedro Paramo. Prevod R. Tatić, predgovor R. Tatić i H. O. Prens. Beograd: Nolit.

Rulfo, H. (2004). Pedro Paramo. Sa španskog prevela D. Radivojević. Novi Sad: Rubikon. Rulfo, H. (2006). Sabrana dela (Pedro Paramo, Dolina u plamenu). Preveli sa španskog R. Tatić i G. Ćirjanić. Čačak: Branko Kukić (Gradac)/Beograd: Fondacija „Radoje Tatić“. 
Rulfo, J. (2011). Pedro Páramo. Con textos introductorios de G. García Márquez, J. Luis Borges y S. Sontag. Barcelona: Editorial RM \& Fundación Juan Rulfo.

Rulfo, H. (2017). Pedro Paramo, Dolina u plamenu. Prevod sa španskog R. Tatić i G. Ćirjanić. Beograd: Dereta.

\section{Интернет странице}

Omaž Huanu Rulfu. Kulturne aktivnosti Instituta Servantes. Dostupno preko: https://cultura.cervantes.es/belgrado/sr/homenaje-a-juan-rulfo/116685?fbclid= IwAR2ZCGGT1csiPsWDLwHOQA9W9ifKcpuWNhfjxw-c-OUOEycJOeZuslxqmiw [06. 03. 2021]

\section{Vladimir J. Karanović}

\section{Snežana B. Jovanović}

Resumen

\section{LA RECEPCIÓN TRADUCTOLÓGICA Y CRÍTICA DE LA NOVELA PEDRO PÁRAMO DE JUAN RULFO EN SERBIA}

Partiendo tanto de los postulados básicos de la teoría de la traducción, de la importancia de la traducción en el determinado medio cultural como del concepto de traducción como primer medio en la comunicación intercultural, en este artículo se aborda el análisis del contexto de la recepción crítica y traductológica de la novela Pedro Páramo del escritor mexicano Juan Rulfo (1918-1986) en nuestro ambiente cultural. El análisis se apoya en el corpus elegido de las traducciones existentes o sus revisiones, mientras como objeto del análisis de la recepción crítica se han elegido los textos que acompañan estas ediciones, publicados en forma de estudios introductorios y postfacios, artículos científicos, igual que los capítulos histórico-literarios de las publicaciones monográficas en el idioma serbio. El aspecto traductológico de la recepción se plantea sobre todo a través del estudio de los rasgos lingüísticos, semánticos y culturales que permitieron que esta obra se integrara más fácilmente en el sistema de la literatura traducida serbia y ocupara un puesto de notable importancia.

\section{Palabras clave:}

Juan Rulfo, Pedro Páramo, literatura mexicana del siglo XX, nueva novela hispanoamericana, recepción traductológica, análisis traductológico comparativo 
Summary

\section{THE TRANSLATIONAL AND CRITICAL RECEPTION OF THE NOVEL PEDRO PÁRAMO BY JUAN RULFO IN SERBIA}

On the basis of the fundamental postulates of translation theory, the importance of translation in a particular cultural environment, as well as of the concept of translation as the first medium in intercultural communication, this paper analyses the context of critical reception and translation of the novel Pedro Páramo by the Mexican writer Juan Rulfo (1918-1986) in the Serbian cultural environment. The analysis is based on the selected corpus of existing translations or their revisions, while the analysis of critical reception focuses on the texts that accompany these editions, published in the form of introductory and epilogue studies, scientific articles, as well as the literary historical chapters of monographic publications in Serbian. The translational aspect of reception is contemplated predominantly through the study of the linguistic, semantic and cultural features that allowed this novel to be more easily integrated into the system of Serbian translated literature and take a position of notable importance.

\section{Key words:}

Juan Rulfo, Pedro Páramo, 20th century Mexican literature, new Latin American novel, translational reception, comparative translation analysis 